\title{
SOUTH CAUCASUS IN THE NETWORK OF INTERNATIONAL RELATIONS
}

\section{ПІВДЕННИЙ КАВКАЗ В СИСТЕМІ МІЖНАРОДНИХ ВІДНОСИН}

\author{
ЮЖНЫЙ КАВКАЗ В СИСТЕМЕ МЕЖДУНАРОДНЫХ ОТНОШЕНИЙ
}

\author{
Chechelashvili V.K.
}

PhD of Economic Sciences, Senior Fellow at the Georgian Foundation for Strategic and International Studies.

\section{Чечелашвілі В.К.}

Кандидат економічних наук, старший науковий співробітник Грузинського фонду стратегічних та міжнародних досліджень

\section{Чечелашвили В.К.}

Кандидат экономических наук, старший научный сотрудник Грузинского фонда стратегических и международных исследований

Abstract. The article considers the problems of divisive lines, separating nations and diminishing prospects of shared prosperity in South Caucasus. Following the collapse of the Soviet Union and the resultant independence for Armenia, Azerbaijan and Georgia, the South Caucasus has primarily been associated with conflicts, hostility, military actions, closed borders. The article highlights the causes of problems and directions for their solutions. An assessment of the development potential of the South Caucasus'and tendencies of establishing a stable and secure space with broad prospects for economic cooperation in the region based on geopolitical and geoeconomic opportunities is made. Arguments are based on variety of different factors, such as the facts that the region has inexhaustible transit and tourist potential, important natural resources of international significance, and an educated, relatively cheap labour force. Attemps are made to resolve issues such as prospects for the South Caucasus to become an attractive region, determined desirable further actions of the regional states and external players (Russia, United States of America, European Union) which are necessary to achieve a result. Expanding European principles, standards and criteria for cooperation in the South Caucasus is the most realistic way for the three states to achieve shared success. Nothing better has been offered in practice with respect to international regional cooperation. The future of the South Caucasus primarily depends on the three states themselves, their ability and vision, the capacity to observe the overall picture of regional developments and assist each other, and shared activity in order to help the population of the states perceive a new reality. The stable and integrated South Caucasus will make a serious contribution to the security system in a broader regional context and will bring greater stability in adjacent areas.

Key words: international conflicts, security system, regional stability, international cooperation, geopolitical opportunities.

Анотація. У статті розглядаються проблеми розмежувальних ліній, поділу наџій $i$ зниження перспектив проивітання держав Південного Кавказу. Після розпаду Радянського Союзу $і$ здобуття незалежності Вірменією, Азербайджаном і Грузією Південний Кавказ, $в$ периу чергу, став асоиіюватися з конфліктами, ворожістю, військовими діями $і$ закритими кордонами. У статті висвітлено причини такої ситуаџї і напрямки для їх вирімення. Дана оцінка потенціалу розвитку Південного Кавказу $i$ тенденцій створення стабільного $i$ безпечного простору з широкими перспективами економічного співробітництва в регіоні на основі геополітичних і геоекономічних можливостей. Аргументи засновані на безлічі різних факторів, серед яких наступні: регіон володіє невичерпним транзитним і туристичним 
потенціалом, важливими природними ресурсами міжнародного значення $i$ освіченою, відносно дешевою робочою силою. Визначено напрямки подальших дій держав Південного Кавказу і зовнішніх гравиів (Росія, Сполучені Штати Америки, Свропейський Союз) з метою перетворення Південного Кавказу в привабливий регіон. Впровадження європейських принципів, стандартів і критеріїв співпраці на Південному Кавказі - найбільш реальний шлях для досягнення успіху. Стабільний і інтегрований Південний Кавказ внесе серйозний внесок в систему безпеки в регіональному контексті і принесе стабільність в прилеглі регіони.

Ключові слова: міжнародні конфлікти, система безпеки, регіональна стабільність, міжнародне співробітництво, геополітичні можливості.

Аннотация. В статье рассматриваются проблемы разделительных линий, разделения наций и уменьшения перспектив общего процветания на Южном Кавказе. После распада Советского Союза и обретения независимости Арменией, Азербайджаном $u$ Грузией Южный Кавказ, в первую очередь, стал ассочиироваться с конфликтами, враждебностью, военными действиями и закрытыми границами. В статье освещень причины такой ситуаџии и направления для их решения. Дана оценка потенцииала развития Южного Кавказа и тенденщий создания стабильного и безопасного пространства $c$ широкими перспективами экономического сотрудничества в регионе на основе геополитических и геоэкономических возможностей. Аргументы основаны на множестве различных факторов, среди которых следующие: регион обладает неисчерпаемым транзитным и туристическим потенциалом, важными природными ресурсами международного значения и образованной, относительно дешевой рабочей силой. Определень направления дальнейших действий государств Южного Кавказа и внешних игроков (Россия, Соединенные Штаты Америки, Европейский Союз) с иелью превращения Южного Кавказа в привлекательный регион. Внедрение европейских принципов, стандартов и критериев сотрудничества на Южном Кавказе - наиболее реальный путь для трех государств для достижения общего успеха. Стабильный и интегрированный Южный Кавказ внесет серьезный вклад в систему безопасности в более широком региональном контексте и принесет стабильность в прилегающие регионы.

Ключевые слова: международные конфликты, система безопасности, региональная стабильность, международное сотрудничество, геополитические возможности.

The main text of article. Geographically, the South Caucasus is undoubtedly a region with well defined natural borders, its space being covered by three independent states - Georgia, Armenia and Azerbaijan.

In the course of its 25 years of independence, the South Caucasus lost the chance, unlike the Baltic states, to establish a stable and secure space with broad prospects for economic cooperation. Just the opposite happened, with the emergence of divisive lines, separating nations and diminishing prospects of shared prosperity. Can this tendency be turned round? One shouldn't underestimate reality. Nevertheless, there is still a chance to ensure a joint contribution to the region's prosperity and sustainable development.

If one does not take the conflicts into account, a simple glance at the map and assessment of the of the South Caucasus' potential is enough to make it clear that there are very few regions that possess such immense geopolitical and geo-economic opportunities. In addition, the region has inexhaustible transit and tourist potential, important natural resources of international significance, and an educated, almost 100\% literate, relatively cheap labour force. In other words, all the necessary factors are in place for the South Caucasus to succeed and to occupy, as a region, a worthy place in international relations networks and to respectively ensure average European living standards for a population with sustainable prospects of further improvement.

Unfortunately, no such positive tendencies can be traced. Following the collapse of the Soviet Union and the resultant independence for Armenia, Azerbaijan and Georgia, the South Caucasus has primarily been associated with conflicts, hostility, military actions, closed borders (this happens in the 21st century), tensions and negative expectations. Why is this happening? 
Could this have been avoided earlier and what should be done to disallow such developments from happening again in the future? Do the three South Caucasian states have a vision, the political will and resources to reverse this situation?

Many publications are devoted to these questions. Almost all authors agree that the South Caucasus is an arena where the interests of major regional and global scale players clash - players who, in pursuing their goals, are guided by their own values and principles of cooperation. Naturally, they affect the development of the situation in a different manner, either motivating regional cooperation and opening up new prospects for the South Caucasus, or else pushing it deeper into the swamp of confrontation and inciting hatred.

What are the prospects for the South Caucasus to become an attractive region and tap into the virtually unlimited potential it possesses, which, until now, has largely gone with the wind? What should the states of the South Caucasus do to achieve this and how can external players influence this process? This study is a modest attempt to answer these complicated questions.

\section{What did we lose in the past and what can we gain in future?}

The South Caucasus is a champion of lost opportunities. Three countries - Armenia, Azerbaijan and Georgia - could have created unique conditions for common development, allowing them to capitalise on their a) lucrative geopolitical and geostrategic location, b) rich natural resources, c) well educated and comparatively cheap labour force, d) good understanding of mutual problems and existing personal channels of communication in practically all groups of society, and e) foreign investor interest. In the case that the South Caucasus become stable, this interest will increase multifold and additional billions will flow into the region from powerful Armenian diasporas alone.

Instead we were dragged into confrontation. External force was skilfully manipulated, along with historic memories and emotional feelings, in order to utilise the classic imperial model of influence based on the "divide and rule" principle. Therefore, the peaceful resolution of the Nagorno - Karabakh conflict is of key importance for regional consolidation. Surprisingly, we must pay tribute to Russian diplomacy - both Armenia and Azerbaijan claim they have perfect relations with Russia.

In the case that the Nagorno-Karabakh conflict reaches a consensus-based resolution, the conflict resolution process regarding Abkhazia and Samachablo will have a strong positive impact. Although we consider this option theoretically, all of this could be realised on the precondition of diminishing Russian capacity to influence regional affairs. Armenia and Azerbaijan, both of which are interested in regional stability due to their individual interests in achieving political success and economic development, will support Georgia, which will feel more confidence and comfortable in seeking peace solutions to its own internal conflicts.

Therefore, first Georgia should assist Armenia and Azerbaijan in finding an acceptable resolution of the Nagorno-Karabakh conflict, and then Armenia and Azerbaijan could help Georgia to find a solution regarding the situation with Abkhazia and Samachablo. Meanwhile, we are losing out, both together and individually.

What are we losing together as an outcome of regional conflicts?

- Stability and security in the region would contribute to the success of the three individual countries;

- Integration and trust would trigger a cumulative effect;

- The South Caucasus region could follow good examples of regional cooperation like the Benelux and Visegrad groups;

- Eventually building up a European model of cooperation: a common space, the four freedoms, and symbolic borders;

- Billions of dollars could be saved, military expenditure substantially downgraded, and living standards upgraded;

- Geopolitical potential is unexploited and the region's common economic and transit potential is underdeveloped; 
- Lacking confidence in the future.

What are we loosing individually?

a) Armenia:

- Investment;

- Trade;

- Transit role;

- Influence in Azerbaijan, the opportunity to participate in Azerbaijan's economic projects;

- The Armenian diaspora would gladly invest in Armenia and the other two countries, thereby reinforcing Armenian influence in the region;

- European prospects.

b) Azerbaijan:

- Investment;

- Trade;

- Territorial integrity.

c) Georgia:

- Investment;

- Trade.

What did we gain individually?

d) Armenia:

- $20 \%$ of their neighbouring state's territory;

e) Azerbaijan:

- Nothing;

f) Georgia:

- Nothing.

In addition to that, we have lost both our authority and reputation in the world community, earned mistrust on the part of international investors, and first of all this applies to Armenia. As an outcome, the region's main investment projects (Baku - Supsa oil pipeline, Baku - Tbilisi - Jeyhan oil pipeline, Baku - Tbilisi - Erzerum gas pipeline, Baku - Tbilisi - Kars railway, Caspian Sea Black Sea Highway) are implemented without Armenian participation.

As a consequences of the Nagorno-Karabakh conflict, the following facts can be confirmed and the following observations made:

1. Casualties, wounded, demolitions, material and immaterial losses, amounting to \$ bln.

2. Generations, raised in the face of hostilities, lack of understanding, non-acceptance of opponents' arguments and unwillingness to listen;

3. Governments are focused on hostilities and predetermined to lag behind as the rest of the world moves forward;

4. Governments are investing our limited resources into war, falling well behind the average world figures regarding GDP per capita;

5. Prospects in the region are aggravated. People in this region have become used to the idea that this is a natural state of affairs;

6. There is a waning sense of stability and security;

7. Trust and understanding between these nations is decreasing. 
Analysis of collective GDP (Armenia, Azerbaijan, Georgia, 2019, \$ bln.) [1;2]

\begin{tabular}{|l|l|l|l|l|}
\hline & Azerbaijan & Armenia & Georgia & Aggregate \\
\hline GDP (nominal, \$ bln.) & 47.17 & 13.44 & 15.93 & 76.54 \\
\hline GDP (nom., p/c, \$ th.) & 4.689 & 4.528 & 4.289 & 4.502 (average) \\
\hline Population (mln.) & 10.02 & 2.95 & 3.72 & 16.69 \\
\hline Area (th.sq.km.) & 82.7 & 28.5 & 69.5 & 180.7 \\
\hline
\end{tabular}

Military expenditure of Armenia, Azerbaijan and Georgia, \$ mln., years of 2010 - 2018. [3;4;5]

\begin{tabular}{|l|l|l|l|l|l|l|l|l|l|}
\hline & 2010 & 2011 & 2012 & 2013 & 2014 & 2015 & 2016 & 2017 & 2018 \\
\hline Armenia & 380 & 348 & 356 & 401 & 407 & 441 & 433 & 444 & 591 \\
\hline Azerbaijan & 1025 & 1951 & 2024 & 2047 & 2054 & 1195 & 1456 & 1529 & 1624 \\
\hline Georgia & 402 & 362 & 375 & 341 & 331 & 294 & 316 & 308 & 312 \\
\hline
\end{tabular}

The volume of military expenditures in aggregate for Armenia for the period 2010-2018 amounted to $\$ 3.801$ bln., fluctuating from 2.7\% to 4.3\% of GDP. For Azerbaijan, this was \$14.905 bln., fluctuating from 2.2\% to 4.6\% of GDP. For Georgia, it was \$3.041 bln., fluctuating from 0.7\% to $9.2 \%$ of GDP. In total, three countries spent almost $\$ 22$ bln for military purposes in the period 2010-2018 alone. In previous twenty years at least \$ 30 bln. was spent for military purposes in the region. As conflicts are there, billions are being spent in addition every year. These developments are aggravated with the feeling of corruption as well. "Expenditures are of course not the whole story. The arms race between Armenia and Azerbaijan has been constantly accompanied by reports and anecdotal evidence of corruption in procurement processes and within military structures... Whatever the scale of corruption, however, there is no doubt that military capabilities have significantly increased”. [6]

At the moment, the three South Caucasus countries are drifting in different directions, thus further deviating from each other. New divisive lines are being established in a small geographically integrated space. The individual security of our countries is downgraded and is costing us much more. Assuming that we are under the same umbrella of security, from three sides we are covered by seas and mountains from the South facing Turkey and Iran. Turkey is NATO member country. Provided we have good relations, NATO offers additional security guarantees. If we were acting together, we would not be dedicating resources to confront each other, but instead we would be collectively strengthening our external perimeter, which is only to the North and South. In this case, this would both be cheaper and more secure.

There are two options regarding collective security arrangements in the South Caucasus: a) Russia and a Russia-dominated Eurasian Union and the CSTO, or b) the EU and NATO. Georgia has already clearly voiced out its choice, when Armenia and Azerbaijan are still manoeuvring. "Armenia has prioritized practical cooperation with NATO over political cooperation, due to circumstances stemming from Russian politics... President Ilham Aliyev, in accordance with his father's approach, has proceeded to implement a partnership with NATO primarily via strategic cooperation with Turkey“. [7]

Three countries policies with respect to these options:

\begin{tabular}{|l|l|l|l|l|}
\hline |Armenia & $\begin{array}{l}\text { Seeks to establish political } \\
\text { contractual relations }\end{array}$ & $\begin{array}{l}\text { LAmited contractual } \\
\text { cooperation due to } \\
\text { CSTO membership }\end{array}$ & member & member \\
\hline Azerbaijan & $\begin{array}{l}\text { Seeks to establish economic } \\
\text { contractual relations }\end{array}$ & $\begin{array}{l}\text { Close cooperation } \\
\text { with NATO key } \\
\text { member Turkey }\end{array}$ & X & X \\
\hline Georgia & Seeks membership & $\begin{array}{l}\text { Seeks membership, X } \\
\text { close cooperation } \\
\text { with NATO key } \\
\text { member Turkey }\end{array}$ & $\mathrm{X}$ \\
\hline
\end{tabular}


These tendency is recognized my many authors. "For the small and economically weak South Caucasus states, efforts to reform their economies and foster good governance should have been areas of cooperation with the West. However, this was not consistently the case in practice. The prioritization of security imperatives continued to a large degree to determine foreign policy orientations - and, by extension, attitudes towards external actors. Thus while the three countries started in broadly the same position in 1990, today their foreign policy paths have diverged”.[8]

Respectively, the region's economic space will be divided along the Georgia-Armenia and Azerbaijan-Armenia borders, and the NATO-CSTO border will again be the Georgia-Armenia border and the Azerbaijan-Armenia border, taking into account bilateral strategic military cooperation between Turkey and Azerbaijan, as well as the quickly developing trilateral military cooperation between Turkey, Georgia and Azerbaijan. After Georgia ultimately joins NATO, Azerbaijan's involvement in the NATO security network will inevitably and considerably be upgraded. We will see friendly neighbouring NATO member countries - Turkey, Georgia and Azerbaijan intensively and closely cooperate with particular interests in security, trade, infrastructure projects, etc.

Under these circumstances, the region will be divided by new lines and Armenia will be marginalized. At the moment, there are no relations with Azerbaijan and Turkey. In addition, a customs border will be established with Georgia that would be legally equal to the Russia-Finland border, as well as a visa regime, that is also similar to the one in force at the Russia-Finland border.

Now there exists a fantastic option: following the positive example of the Baltic States, the three South Caucasian countries are moving towards the European Union and NATO. They are supporting each other, rather than competing. Eventually Georgia and Armenia will become EU and NATO members, while Azerbaijan, similarly to Norway, is a NATO member with a strong contractual relationship with the EU, including upholding the four freedoms (free movement of goods, services, capital and people), energy cooperation, etc. A South Caucasian version of Benelux could be called Azgear.

Azgear would mean:

- A common market;

- A shared external security system;

- Strong stability and security guarantees;

- Much more resources with a multiplication effect;

- Shared infrastructure projects;

- Increased attractiveness of the region;

- Dozens of billions in additional FDI;

- Better living standards;

- Better prospects for future generations.

These opportunities are well described by many experts, including former Heads of Diplomatic Missions to the region. "It is time for the South Caucasians to make up their minds about their future. If they want closer cooperation with the West, they must pursue reforms for transparent governance and wider economic opportunity. As the countries grapple with their choices, the West must keep faith with those advocating reforms and freedom”.[9]

We face two possible ways of development: further deviation / separation from each other or a South Caucasus Union, like the Azgear mentioned previously. This entails a choice between fantastic, immense prospects or endless fighting and turbulence. Generations are being brought up with such negative experience. Those who were born in 1985 or after hear only about hatred and war. Today they are over thirty, entering an active phase of activity, including in politics. We have only ten years to establish peace and stability in the South Caucasus - time is running out and prospects are fading.

We have some important examples in history to recall and draw conclusion from. Many thousands of French and German soldiers gave their lives over centuries of fighting for Alsace and Lorraine. Nowadays, the border between France and Germany exists only on the map. When 
crossing, one can hardly notice it. More than that, Germany and France constitute the backbone of the EU, pushing together a shared European agenda.

What will happen if this separation continues and the set of foreign policy priorities for Georgia, Armenia and Azerbaijan end up moving further from one another? The worst possible option would be to draw new dividing lines, if not implementing an iron curtain in the region. This sounds like a fantastic theory, although a lot of scenarios that were treated fantastic some time ago, had already been turn into reality. "As Georgia has recently deepened its ties with the European Union and Armenia has committed itself to the Eurasian Economic Union, the whole region will be affected".[10]

External players play their games with conflicting interests and goals, some of whom exploit differences and contradictions. In addition, one of the main regional powers - Russia - is openly fuelling hostilities among the three countries. As on result, the South Caucasian states don't have a common agenda, a collective vision, or even shared goals and objectives. Georgia, Armenia and Azerbaijan are weaker separately than they would be united.

\section{Strengthening Democracy, Promoting Reform and Reducing Poverty}

Every government's mission is to ensure better living standards for its population. This can be reached by strengthening democracy, rule of law and the market economy. But, in a state of war, the government pretends, some think rightly, that its main Mission is to defeat the enemy - this message is clear, understandable and easy for people to share. And this is a rather strong temptation that should be avoided.

For any government to develop democracy, it is necessary to have political will, vision and resources (both human and financial). This is a lengthy and capacity consuming process, which requires a sustainable approach and continuity to ensure development and consolidation, and to increase the stability and effectiveness of democratic institutions.

An integral part of this process is strengthening the rule of law, the independence of the judiciary, pursuing public administration reform, establishing a compact, well - structured, concise and professional civil service, and the effective functioning of institutions in the areas of law enforcement and market economy.

For a state in war, the political will lies in defeating the enemy, and its vision doesn't typically reach beyond defeating the enemy. In such a situation, it is very easy to label opponents of the government as enemies of the state/people. [11] Hostility and the factual state of war diverts resources that are vitally needed to develop democracy and fight poverty. What is also dangerous is that conflicts stimulate authoritarianism; they demand authoritarian rule. "The irony of the Nagorno-Karabakh situation is that, over the last two decades, two states brandishing almost civilization differences have turned into uncanny mirrors of one another. Their political developments haven't been so much paralyzed by the conflict as altogether hijacked by it: electorates in Baku and Yerevan are hostage to mimicking narratives claiming that national prosperity will come only when Nagorno-Karabakh is under their country's own undisputed control”. [12]

Due to the fact that living standards are not at the top of the government's agenda, it is difficult to defeat poverty. Resources, even limited, are directed toward military needs, poverty grows, and the opposition's capacity dwindles.

Some food for thought on the reforms implemented by Georgia, Armenia and Azerbaijan, can be derived from several indices, which have been provided by international institutions. Position of the South Caucasian states in Corruption Perception Index 2014 - 2019 [13]

\begin{tabular}{|l|l|l|l|l|l|l|}
\hline Country & 2019 rank & 2018 rank & 2017 rank & 2016 rank & 2015 rank & 2014 rank \\
\hline Georgia & 44 & 41 & 46 & 44 & 48 & 51 \\
\hline Armenia & 77 & 105 & 107 & 113 & 95 & 94 \\
\hline Azerbaijan & 126 & 152 & 122 & 123 & 119 & 126 \\
\hline
\end{tabular}


Position of the South Caucasian states in World Rankings [14;15]

\begin{tabular}{|l|l|l|l|l|l|l|}
\hline & $\begin{array}{l}\text { Hunan } \\
\text { development } \\
(2018)\end{array}$ & $\begin{array}{l}\text { Ease of } \\
\text { doing } \\
\text { business } \\
(2019)\end{array}$ & $\begin{array}{l}\text { Global } \\
\text { competitiveness } \\
(2018)\end{array}$ & $\begin{array}{l}\text { Corruption } \\
\text { perceptions } \\
(2019)\end{array}$ & $\begin{array}{l}\text { Economic } \\
\text { freedom } \\
(2019)\end{array}$ & $\begin{array}{l}\text { Property } \\
\text { rights } \\
\text { (2019) }\end{array}$ \\
\hline Georgia & 0.79 & 83.50 & 60.88 & 56.00 & 75.90 & 5.25 \\
\hline Armenia & 0.76 & 73.19 & 59.86 & 42.00 & 67.70 & 4.81 \\
\hline Azerbaijan & 0.75 & 73.59 & 60.04 & 30.00 & 65.40 & 5.12 \\
\hline
\end{tabular}

Position of the South Caucasian states in Easy Doing Business Index 2019 [16]

\begin{tabular}{|l|l|l|l|l|l|l|}
\hline Country & 2019 rank & $\begin{array}{l}\text { Starting } \\
\text { Business }\end{array}$ & $\begin{array}{l}\text { Dealing } \\
\text { with } \\
\text { Construction } \\
\text { Permits }\end{array}$ & $\begin{array}{l}\text { Registering } \\
\text { Property }\end{array}$ & $\begin{array}{l}\text { Getting } \\
\text { Credit }\end{array}$ & $\begin{array}{l}\text { Trading } \\
\text { Across } \\
\text { Borders }\end{array}$ \\
\hline Georgia & 7 & 2 & 5 & 2 & 4 & 16 \\
\hline Armenia & 47 & 5 & 13 & 5 & 14 & 14 \\
\hline Azerbaijan & 34 & 4 & 12 & 12 & 2 & 19 \\
\hline
\end{tabular}

The main conclusion that can be drawn from the above tables is that all three countries of the South Caucasus are carrying out impressive economic reforms, especially in the field of facilitating business freedom. One can only regret that the "political breaks" in the region do not provide an opportunity to use the emerging opportunities in aggregate. On regional level this would significantly enhance the positive effect. What is particularly important, the authority and reputation of the South Caucasus in the network of international relations would be significantly upgraded with all the respective consequences.

\section{Who is interested in South Caucasus conflicts?}

The South Caucasian states have a long and complicated history of relations dating back thousand years and its analysis would extend far beyond the format of this article. At the beginning of the 1920s, all three states lost their independence upon being invaded by Soviet Russia, after which they lived together with "the family of brother nations" for almost 70 years. These "brotherly relations" turned out to be an illusion, as they couldn't manage to resist the first serious challenge triggered by an external source. This policy was generated in Moscow, then capital of what was then Armenia's and Azerbaijan's common country - the Soviet Union. Only with Moscow's consent could a big amount of weapons be flown into the region.

Ironically, the main mediator of the Nagorno-Karabakh conflict is Russia, who is not interested in reaching a peaceful resolution to this conflict. In other words, to be more precise, Russia is interested in keeping this conflict outside the framework of peaceful resolution. In this case, the "divide and rule" principle, which is already well tested in conflict regions of independent states, has been used to organise a clash between two neighbouring states. Surprisingly, both Armenia and Azerbaijan claim to have excellent relations with Russia. Obviously Armenia has greater grounds for such a claim. The other sad side of this story is that: a) the elites of both rivals are likely to speculate and manipulate the current situation to ensure their self long-standing political and economic interests, and b) the peoples of these conflicting states are getting used to this state of affairs.

The peaceful coexistence of Azerbaijani and Armenian diasporas in Georgia and namely in Tbilisi demonstrates that ethnic hatred between the two is not inevitable. In the Georgian state, as well as in its capital, the two nationalities managed to live in peace through these turbulent years, when tensions accelerated between Armenia and Azerbaijan over the Nagorno-Karabakh war. Ethnic minorities, including Armenians and Azerbaijanis, together with the Georgians, have gotten through difficult times together - with no job, no salary, no pension, no medical service, no heating season, and no electricity - but still we all managed to live peacefully. This may be one of the most 
important achievements of the Georgian state, the importance of which is still underestimated. This is a vivid demonstration of the fact that Azerbaijanis and Armenians can live in peace as neighbours, provided that the environment is healthy and there is no force coming from outside to try pollute the atmosphere in order to play the specific game of implementing its own agenda.

\section{The Role of Regional Cooperation in Promoting Security and Stability}

Regional cooperation, a manifestation of multilateral interaction of neighbouring and adjusting states, is based on and is dependant on the quality of bilateral relations, and also eventually contributes to regional security and stability through better trust and understanding, developing a common feeling of the region, its role and place in the network of international relations. Each state strives to upgrade its "weight" in the sphere of regional cooperation, as it leads to improved authority and reputation. Consequently, when it occurs simultaneous to bilateral cooperation, regional interaction gives the state the additional capacity to assert its interests on the international arena and to implement its national foreign policy agenda.

A state's security is based on many components and depends on the quality of the cooperation space established in the immediate neighbourhood. The concept of "common and indivisible security" has been established in practice, which means that each state has an equal right to be secure and that a state's security is inseparably linked to that of all others. This is true, both universally and regionally. In addition, if neighbours share common values and cooperation standards, the region becomes secure, competitive and prosperous. Although experiencing some problems currently, the European Union may still serve as a good example.

We have witnessed a lot of dramatic developments in the last decade, but this is not the end of the story. Much needs to be done to prevent further aggravation of the situation in the region and to consolidate efforts in order to ensure full respect for the principles and norms of international law and their unconditional implementation. The OSCE's 10 basic principles are of particular importance in this respect, as they establish a solid foundation for the new security system in Europe.

Concerted effort is needed to force states that violate internationally recognized norms and principles of international la, to return to the commonly accepted rules of the game. This concerted effort is needed both at a universal and the regional level. Is the South Caucasus a region with the capacity to contribute to this process?

Different focus groups are trying to find answer to this question. One of the attempts was made by the Georgian Foundation for Strategic and International Studies on 19 February 2016. [17]

Representatives of the Ministry of Foreign Affairs, the President's Administration, and independent experts from various institutions have elaborated on the matter, trying to visualise prospective formats for regional cooperation. An attempt was made to assess the regional set up and to leverage multilateral diplomacy to promote lasting and sustainable security. A number of regional formats were analysed, three of which were recognised as particularly interesting: the Black Sea Economic Cooperation (BSEC), the Organization for Democracy and Economic Development - GUAM (GUAM), and the Turkey-Georgia-Azerbaijan trilateral format. GUAM and the Turkey-Georgia-Azerbaijan trilateral format have an advantage in this sense, as the participating states share the same vision and goals, based on the same understanding of the norms and principles of international law.

It is worth mentioning that, in the discussions, Armenia was mentioned only hypothetically. The fact is that 10 out of 14 Armenian check points are not operational. They are blocked due to a hostile relationships with Turkey and a state of war with Azerbaijan. "Of course, Yerevan would like to diversify its international ties, including deepening its economic relationship with Europe, but the closure of its own borders with Azerbaijan and Turkey and the presence of more than 5000 Russian troops on its territory limit Armenia’s options”.[18]

At the same time, all participants shared the same attitude which is that, provided that Armenia resolves its problems with two (Azerbaijan and Turkey) of its four immediate neighbours, this would open fantastic opportunities for the South Caucasus region. It was unanimously felt that 
this will become possible when Russia's influence on the elaboration and implementation of Armenia's eventually decreases dramatically. The Russian Federation demonstrated its influence when, in November 2013, Armenian authorities decided almost overnight to put aside the Association Agreement with the European Union, which they were ready to sign, in favour of a Russian-led Eurasian Union. [19]

The declared goals of all international regional organisations virtually coincide - promoting regional interaction through the establishment of a respective legal basis and implementation of regional projects and programs of cooperation, which should eventually contribute to greater stability, security, understanding and trust in the region. But a big question remains: how successful are existing regional formats in implementing these goals?

Unfortunately, these goals cannot be realised through existing formats. Accordingly, the process of searching out alternatives is also not completed. It would be better if this process were guided by the common vision to establish stronger consolidation based on shared values, as well as standards and principles of cooperation.

In the current situation, due to the Russian Federation's strong influence/interference in regional affairs, the prospect of this happening is gloomy. As a result, Armenia's role in the regional cooperation network is limited, and all regional projects implemented so far in the region have bypassed Armenia's territory. With the Baku-Tbilisi-Kars railroad connection becoming operational later this year, even the existing infrastructure of the railroad network in Armenia will become obsolete and unnecessary for international transportation needs. It is time for Armenia to think about more active regional engagement.

\section{The Role of Russia}

Russia has problems of a different quality and character than almost all of its neighbours, from the Baltic States to Japan. Only a couple of Russia’s neighbours, Armenia being one of them, pretend to have excellent relations with the Kremlin. Although this is a highly disputable assertion, considering the latter's policy towards its neighbours, particularly during last decade.

The first vivid demonstration of Russia's true intentions in the post-Soviet space surfaced as an outcome of the August 2008 Russian-Georgian war, the first war of the 21st century. After this happened, the Russian Federation occupied two disputed regions of Georgia and recognised them as independent states.

Foreign Minister Lavrov, apparently in aims of appeasing world opinion, declared at a meeting of the Federation Council on September 18, 2008: "Russia will actively promote the peaceful resolution of all conflicts in the CIS area on the basis of international law, respect for the UN Charter principles, and agreements reached earlier between the parties involved in the conflict. We will pursue our mediation in the negotiation process; this fully applies to Transnistria and Nagorno-Karabakh. There exist their own peculiarities, formats and mediation mechanisms everywhere. But the South Ossetian crisis does not create any precedent for them". "There are no parallels here. Thank God, Saakashvili is the only exceptional event of this kind," emphasized the head of the Russian Foreign Ministry. [20] Many experts and politicians in Europe and the former Soviet Union then sighed with relief. The hypocrisy of this statement was fully manifested only five and a half years later, on March 18, 2014, when Russian President Vladimir Putin addressed the State Duma with the request to include two new legal entities into Russia's composition - the Crimea and the city of Sevastopol. It worth recalling that the Ukrainian army did not make a single shot in the Crimea, but Russian military troops landed on the territory of a sovereign state, seized the authorities, including the local parliament and, under military threat, organized a so-called fancy "referendum". "Russia's annexation of Crimea and subsequent support of the insurgency in the Donbass region of Ukraine beginning in 2014 brought on the biggest crisis in post-Soviet relations between Russia and the West and this situation has deeply impacted the states of the South Caucasus”.[21]

Looking back, in the autumn of 2008, Georgian diplomats had tried to explain, during meetings in public and with colleagues, that Russia's policy towards Georgia is not an exception, 
but rather an extreme manifestation of its usual policy towards neighbouring countries. Now this extreme manifestation can be witnessed with regard to Ukraine. One day, the Kremlin may decide it is necessary to further assert its influence in the region and no international agreement, even legally binding ones, will constitute any problem for it. We have now seen this number of times. [22]

In this light, it is worth mentioning, in particular, the Budapest Memorandum of 1996. The signatures of United Nations Security Council permanent members, which are not regular Russia's neighbours, were ignored. As an outcome, a crisis of trust between the main international players erupted, dragging the world back to the cold war period. Under existing circumstances, what was done to Georgia or Ukraine can ultimately happen with any neighbour of the Russian Federation.

Still there is a sign of hope because, despite all these problems, the South Caucasus is still a region: the three countries have too many factors in common, although this will not last forever. We need a permanent solution to this problem, which should accommodate the interests of all sides and provide respective guarantees.

The Madrid Principles represent one of the most successful attempts to find a solution to peace settlement of Nagorno Karabakh conflict. Based on Helsinki Final Act, they contain still unexplored opportunities. The most controversial of the Principles seem to be number six, referring to Peace Keeping Forces (PKF). "PKF units shall be drawn from nations that volunteer troops. The selection of troops for the PKF shall be done by the parties by mutual consent. Each party has the right to veto the other's choice”. [23] “Although the deployment of peacekeepers has been hypothetically accepted by the parties and the OSCE, there is no consensus on scenarios. For the conflict parties, it is hard to imagine the introduction of a major new actor on the ground in a context that has seen no change in more than 20 years”. [24]

Below are presented some ideas in development of Madrid Principles with special emphasis on the issue of PKF, outlining possible contribution of Georgia.

A permanent decision could be a sustainable conflict resolution process with guarantees to all sides, containing a number of main components: a) ceasefire and withdrawal of heavy weapons under international control, like the OSCE, declaring a 20-kilometre weapon-free zone; b) returning all districts beyond the administrative borders of Nagorno Karabakh to Azerbaijan, with guaranteed access between Armenia and Nagorno-Karabakh; c) opening all communications in the region, including the Armenia-Turkey border; d) postponing consideration of the status of NagornoKarabakh for ten years; e) horizontal economic cooperation regarding Nagorno-Karabakh with both Azerbaijan and Armenia; f) returning the displaced population to their homes in NagornoKarabakh, and later to Azerbaijan and Armenia; g) the composition of the OSCE lead PKF should be carefully crafted to involve nations that enjoy the full trust of all sides. Possibly these can be units of the Georgian army, consisting of ethnically Azerbaijani and Armenian Georgian citizens (Georgians would be included as well), trained together through a special program. Georgian units trained for participation in NATO operations may serve as a basis.

However, this could all happen when Russia's capacity to influence the situation will be restricted. Despite the fact that nearly three decades of Russian mediation didn't produce any tangible results, Russian diplomacy is not particularly concerned about this. The magic position for Russian diplomats is that after the Parties to the conflicts themselves reach a consensus on the formula for conflict resolution, Russia will support it. This is a rational position, provided that the mediator is not supplying weapons to conflicting States and that it is sincerely interested in the conflict resolution process. This is true not only to Nagorno-Karabakh, but any other conflict in the post-Soviet space. As an outcome, Russian mediation efforts lead either to a continued conflict (Nagorno Karabakh, Transdnestria), usurping part of the territory of a neighbouring state (Abkhazia, South Ossetia), direct annexation (the Crimea), or provoking hostilities and conflict (eastern Ukraine).

\section{Role of the European Union}

The role of regional cooperation in European integration processes is increasing and the European Union encourages such cooperation, in particular in the Caspian-Black Sea region, of which the South Caucasus is an integral part. [25;26;27] 
The EU has a long history of cooperation with all three South Caucasian countries. The EU, despite differences between countries, has always promoted regional projects, motivating Georgia, Armenia and Azerbaijan to become closer to the EU, to implement the respective reform policy, and to improve understanding and trust amongst each other. This approach offers an excellent opportunity for South Caucasian states to demonstrate sustainable and predictable policy, based on European values and standards of cooperation.

Demonstrating the EU's strong regional approach is the fact that Partnership and Cooperation Agreements have been signed at a joint ceremony in Luxemburg on April 22, 1996 [28], and that the same European Neighbourhood Policy [29] and Eastern Partnership [30] instruments were offered later to all three states. To date, only Georgia had signed a EU Association Agreement [31]. Later EU - Armenia Comprehensive and Enhanced Partnership Agreement [32] was signed. EU is continuing the negotiation process with Azerbaijan, aiming to promote European standards and principles of cooperation in the whole region of the South Caucasus.

The experience of the Baltic and Visegrad 4 countries has proven that, when applying European standards, principles, traditions and the spirit of cooperation, a group of neighbouring countries can impressively progress towards and become closer with the EU. This is a good example to follow. Provided that the three states will follow the Baltic and Visegrad 4 pattern and philosophy of cooperation, qualitatively new, immense development opportunities will surface in the South Caucasus.

In basing cooperation in the South Caucasus on European principles and practices and trying to approach European standards, Georgia, Armenia and Azerbaijan can ultimately establish much better living standards in the region, as well as developing a cooperative spirit.

Consequently, it is difficult to overestimate the place and role of the EU in the process of bringing the South Caucasian states closer to one another and also in promoting better security and stability within the region. Although this is long process, there is no alternative. New EU - Armenia Comprehensive and Enhanced Partnership Agreement and EU - Azerbaijan negotiations give hope for the further Europeanization of the South Caucasus. [33]

What can Georgia contribute to improve the cooperative spirit in the South Caucasus?

Georgia is a multinational country, wherein Armenians and Azerbaijanis have traditionally comprised the biggest national minorities. According to census of November 2014, a total of 233,024 Azerbaijanis and 168,102 Armenians were registered in Georgia.

The Georgian region of Kvemo Kartli is predominantly inhabited by Azerbaijanis $(177,032)$, just as Samtskhe - Javakheti is inhabited by Armenians $(81,089)$. Although these regions neighbour each other, during years since the Soviet Union's collapse, when the Nagorno Karabakh conflict was going through the different phases of hostilities, there were no clashes happening between neighbouring Armenians and Azerbaijanis.

Neither were there any conflicts between the two national minorities in Tbilisi, where 15,187 Azerbaijanis and 53,409 Armenians live predominantly in neighbouring districts of Avlabari and Abanotubani [34]. This is a promising sign and vivid demonstration of the fact that cooperation, a good neighbourhood, and even friendship between Azerbaijanis and Armenians is not something unimaginable. 


\section{Regions of Georgia [35]}

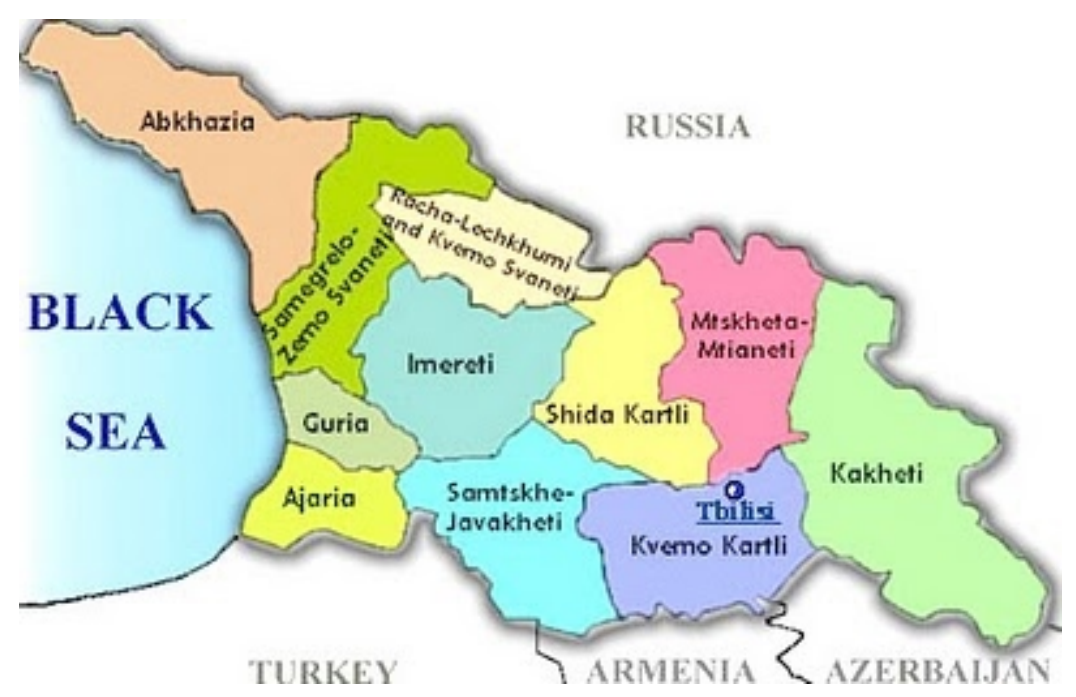

Probably the best example of peace and the friendly attitude of Azerbaijani and Armenian diasporas can be found in the two Georgian villages of Tsopi and Khonjurni, which are located near the Georgia-Armenia border. Both diasporas live in these villages, with Azerbaijanis dominating in Tsopi and Armenians in Khonjurni. [36]

The peaceful and even friendly coexistence of two ethnic groups is impressively described by British journalist and photographer Onnik James Krikorian as detailed on his website. [37]

In the case that the Georgian Government pays more attention to the mentioned villages by allocating more investment into infrastructure and jobs, this pattern may play a more significant role for the region as a whole. One of the options is to utilise these villages to create a platform for dialogue regarding the South Caucasus, leading to greater understanding, stronger security and increased stability. At the minimum, we will gather some additional hope for future.

\section{Conclusions}

1. During the thirty years that have passed since the collapse of the Soviet Union and achieving independence, the states of the South Caucasus have not taken advantage of the impressive potential entailed in regional cooperation, their attractive collective geopolitical and geoeconomic position, and transit capacity.

2. The South Caucasus has gone through different periods of history, but this stage of development is particularly important, as its ability to build a strong, developing and successful region is decreasing. In theory, it is possible to build a successful state individually, outside the regional context, although the EU accession process demonstrates that a regional collective effort proves to be much more effective.

3. The establishment of a community of states in the South Caucasus like the Baltics, the Visegrad 4, or moreover, Benelux, is still a hard-to-imagine dream. This dream is described in the study as Azgear.

4. Armenia's accession to the Eurasian Union and the Customs Union has limited the possibilities for regional cooperation in the South Caucasus. In the long term, this may even lead to problems implementing the Bilateral Free Trade Agreement with Georgia.

5. The Madrid Principles seem to be providing the most realistic prospective vision to date in terms of a peaceful process for resolving the Nagorno-Karabakh conflict. Success may turn into an important contribution to a comprehensive European security system and Georgia, as a homeland to numerous Armenian and Azerbaijani diasporas, may play a more active role at the stage of implementing decisions, including future peace keeping operations.

6. The European Union and Armenia initialled the text of the EU-Armenia Comprehensive and Enhanced Partnership Agreement on March 21, 2017. On November 14, 2016, 
the Council adopted a mandate for the European Commission and the High Representative for Foreign Affairs and Security Policy to negotiate a comprehensive agreement with the Republic of Azerbaijan on behalf of the EU and its member states. Such developments leave hope in regards to promoting European principles, standards and criteria for cooperation in the South Caucasus.

7. Expanding European principles, standards and criteria for cooperation in the South Caucasus is the most realistic way for the three states to achieve shared success. Nothing better has been offered in practice with respect to international regional cooperation. A perfect example in this regard is overcoming the long bloody confrontation between neighbouring states over the problem of Alsace and Lorraine.

8. The states of the South Caucasus spend large amounts of state finances on military expenditures - this entails the risk of corruption, limits development opportunities, and ultimately weakens both collective and individual security.

9. Conflicts and confrontation reduce the international community's credibility towards the states of the South Caucasus. Investors are scared to invest in the region. Armenia apparently suffers the most from this, but, given the appropriate conditions, Armenia could become the region's leader in terms of attracting foreign direct investments, particularly taking into account the opportunities of the Armenian diaspora.

10. The future of the South Caucasus primarily depends on the three states themselves, their ability and vision, the capacity to observe the overall picture of regional developments and assist each other, and shared activity in order to help the population of the states perceive a new reality.

11. There is still an opportunity to give the South Caucasus a new lease of life and a second wind, which can take it through the problems lying ahead. This would be possible, provided that it is accompanied by patience and tolerance. A restructured political will and efforts to understand the opponent's view could become the heart of change.

12. The security and stability, economic development and integration of the South Caucasus largely depends on the degree of democratization of Russia as the most powerful regional player; At present the Russia is only external force, which links its own interests and influence strengthening capacity in the South Caucasus with destructive actions, including using brutal military force and arms trade.

13. The European Union and the United States of America should play a stronger and more active role in all formats of the negotiation process in order to achieve the peaceful settlement of conflicts in the South Caucasus, as well as in the process of building a stimulating environment for the region's political stability and economic prosperity.

14. Time is running to show radical improvements in the culture of cooperation and the quality of targets, ultimately building up a common vision to treat the region as a shared space for three nations and a means of embodying common interests. Otherwise, the South Caucasus will lose the chance to modernise the region and further integrate it into the wider dynamic tendencies entailed in trans European cooperation processes.

15. The stable and integrated South Caucasus will make a serious contribution to the security system in a broader regional context and will bring greater stability in adjacent areas.

\section{References}

1. Source: https://knoema.com/atlas/Armenia?compareTo=AZ

2. Source: https://knoema.com/atlas/Armenia?compareTo=GE

3. 3 Source:. https://tradingeconomics.com/armenia/military-expenditure;

4. Source: https://tradingeconomics.com/azerbaijan/military-expenditure;

5. Source: https://tradingeconomics.com/georgia/military-expenditure

6. Laurence Broers;; The Nagorny Karabakh Conflict Defaulting to War, p.6; Chatham House, the Royal Institute of International Affairs; Russia and Eurasia Programme; July 2016; Available at: 
https://www.chathamhouse.org/sites/files/chathamhouse/publications/research/NK\%20paper\%2024 082016\%20WEB.pdf

7. $\quad$ Eduard Abrahamyan; The South Caucasus: United, and Divided, by NATO; p.2, June 9, 2016; The National Interest Magazine; Available at: http://nationalinterest.org/feature/the-south-caucasusunited-divided-by-nato-16534

8. George Mchedlishvili; Changing Perceptions of the West in the South Caucasus Adoration No More, p.6; Chatham House, the Royal Institute of International Affairs; Russia and Eurasia Programme; February 2016; Available at: https://www.chathamhouse.org/sites/files/chathamhouse/publications/research/2016-02-12-westsouth-caucasus-mchedlishvili-final.pdf

9. Denis Corboy, William Courtney, Richard Kauzlarich and Kenneth Yalowitz; Choices for the South Caucasus, August 28, 2013, The New York Times; Available at: http://www.nytimes.com/2013/08/29/opinion/global/choices-for-the-south-caucasus.html

10. Suvi Kansikas and Mikko Palonkorpi; The South Caucasus beyond Borders, Boundaries and Division Lines Conflicts, Cooperation and Development Edited by Mikko Palonkorpi 2015; Chapter 9 The EEU, the EU and the New Spheres of Influence Game in the South Caucasus, p.200; The publication has been supported by the Ministry for Foreign Affairs of Finland; Available at: http://www.helsinki.fi/aleksanteri/english/publications/files/South_Caucasus_Beyond_Borders.pdf 11. Azerbaijan - Armenia conflict: patriotism prevails on both sides; The Guardian; Available at: https://www.theguardian.com/world/2016/apr/07/azerbaijan-armenia-nagorno-karabakh-patriotismprevails-on-both-sides

12. Alexander Clapp; Prisoner of the Caucasus, Nagorno-Karabakh: a clash of civilizations?; p.4, February 16, 2017, The National Interest Magazine; Available at: http://nationalinterest.org/feature/prisoner-the-caucasus-19473?page $=4$

13. Source: https://www.transparency.org/en/cpi/2019/results

14. Source: https://knoema.com/atlas/Armenia?compareTo=AZ;

15. Source: https://knoema.com/atlas/Armenia?compareTo=GE

16. Source: http://www.doingbusiness.org/rankings

17. Discussion on "Multilateral Cooperation in South-Eastern Europe", GFSIS, February 19, 2016; Available at: http://gfsis.org/events/meetings-and-discussions/view/552

18. Andrew C. Kuchins, Jeffrey Mankoff; The South Caucasus in a Reconnecting Eurasia, p.5; Centre for Strategic and International Studies; October 2016; 1616 Rhode Island Avenue, NW, Washington, DC, 20036; Available at: https://csis-prod.s3.amazonaws.com/s3fspublic/publication/161007_Kuchins_SouthCaucasusReconnectingEurasia_Web.pdf

19. Vano Chkhikvadze; The South Caucasus and the EU - Different Path for Each Country; November 18, 2016; Available at: https://eu.boell.org/en/2016/11/18/south-caucasus-and-eudifferent-paths-each-country

20. Transcript of speech by Minister of Foreign Affairs of Russia Sergey Lavrov at the Extended Meeting of the Committee of the Council of the Federation for International Affairs, Moscow, September 18, 2008; Available at::http://www.mid.ru/meropriyatiya_s_uchastiem_ministra//asset_publisher/xK1BhB2bUjd3/content/id/324594

21. Andrew C. Kuchins, Jeffrey Mankoff; The South Caucasus in a Reconnecting Eurasia, p.3; Centre for Strategic and International Studies; October 2016; 1616 Rhode Island Avenue, NW, Washington, DC, 20036; Available at: https://csis-prod.s3.amazonaws.com/s3fspublic/publication/161007_Kuchins_SouthCaucasusReconnectingEurasia_Web.pdf

22. Valeri Chechelashvili; Russia - Ukraine: The Causes of the Crisis and What Will Happen Next, Georgia, Tbilisi, GFSIS, February 2017; Available at: http://gfsis.org/library/view-opinionpaper/71

23. Basic principles for a peaceful settlement of the Nagorno-Karabakh conflict, transmitted at the OSCE Ministerial Council (Madrid, 29 November 2007) as an official proposal of France, the Russian Federation and the United States of America, as Co-Chairs of the OSCE Minsk Group, for 
consideration by the Presidents of Armenia and Azerbaijan (p. 6); Available at: http://www.aniarc.am/2016/04/11/madrid-principles-full-text/

24. Securing an Armenian-Azerbaijani agreement: the roles of international and local security providers; Discussion Paper, June 2015; Conciliation Recourses - an independent international organization working with people in conflict to prevent violence, resolve conflicts and promote peaceful societies; Available at: http://www.c-r.org/downloads/150714_Securing\%20ENG.pdf

25. Source: http://eeas.europa.eu/archives/docs/enp/pdf/pdf/com07_160_en.pdf.

26. Source: https://ec.europa.eu/neighbourhood-enlargement/neighbourhood/eastern-partnership_

en.

27. Source: https://ec.europa.eu/neighbourhood-enlargement/neighbourhood/eastern-partnership_

en.

28. Tigran Mkrtchyan, Tabib Huseynov and Kakha Gogolashvili, The European Union and the South Caucasus Three Perspectives on the Future of the European Project from the Caucasus Europe in Dialogue 2009 | 01; Available at: http://www.bertelsmannstiftung.de/fileadmin/files/BSt/Publikationen/GrauePublikationen/EiD200901EuropeanUnionandSo uthCaucasus.pdf

29. European Union External Action; European Neighbourhood Policy (ENP);December 21, 2016; Available at: https://eeas.europa.eu/headquarters/headquarters-homepage/330/europeanneighbourhood-policy-enp_en

30. European Commission; European Neighbourhood Policy and Enlargement Negotiations; Eastern Partnership (EP); Available at: https://ec.europa.eu/neighbourhoodenlargement/neighbourhood/eastern-partnership_en

31. European Union, External Action, EU - Georgia Association Agreement; Available at: https://eeas.europa.eu/headquarters/headquarters-homepage_en/9740/EU/Georgia\%20Association\% 20Agreement

32. https://eeas.europa.eu/sites/eeas/files/eu-armenia_comprehensive_and_enhanced_partnership_ agreement_cepa.pdf

33. European Council, Council of the European Union; EU to launch negotiations on a new agreement with Azerbaijan, November 14, 2016; Available at: http://www.consilium.europa.eu/en/press/press-releases/2016/11/14-azerbaijan/

34. Source: https://ru.wikipedia.org/wiki/Перепись_населения_Грузии_2014\#.D0.9D.D0.B0. D1.86.D0.B8.D0.BE.D0.BD.D0.B0.D0.BB.D1.8C.D0.BD.D1.8B.D0.B9_.D1.81.D0.BE.D1.81.

35. Source: https://sites.google.com/a/iliauni.edu.ge/sakartvelo-da-turizmis-ganvitareba/ sakartvelos-regionebi

36. See more: In Georgian village, Armenians and Azeris Find Common Ground; Radio Free Europe, Radio Liberty, June 24, 2013; Available at: http://www.rferl.org/a/25046864.html

37. Onnik James Krikorian, Journalist, Photographer, Media Consultant, Available at: http://onnik-krikorian.com 